\title{
Does accounting treatment of share-based payments impact performance measures for banks?
}

\section{Summary at a glance}

This paper evaluates the resulting impact of mandatory expensing of Share-Based Compensation (SBC) under IFRS2/FASB123R on a set of widely used performance measures in the EU and US banking industry. The findings show that the impact seems to be material, yet modest, for US banks and only for large and high growth EU banks. Banks also continue to use SBC but there is a reduction, albeit insignificant, in the recognised SBC expense. The findings also show a marked movement towards using cash-settled based payments.

\begin{abstract}
This paper identifies, evaluates, and analyses the resulting impact of mandatory expensing of Share-Based Compensation (SBC) under IFRS2/FASB123R on a set of widely used performance measures in the EU and US banking industry. The paper shows that the accounting treatment of SBC schemes, following the mandatory adoption of IFRS2/FAS123R, has a statistically significant negative impact on the selected performance measures over the period 2004-2011. The impact also seems to be material, yet modest, for US banks and only for large and high growth EU banks, indicating that earlier public concerns and criticisms of the implementation of IFRS2/FAS123R are largely unsubstantiated. The findings also show that banks continue to use SBC, but there is a reduction, albeit insignificant, in the recognised SBC expense over the period 2009-2011. That is, earlier public concerns that firms would curtail employing SBC in their employees' compensation schemes to avoid the effect of SBC expense recognition on their financial ratios came to light after the first option life-cycle in the post-adoption period was over. The findings also show a marked movement towards using cash-settled based payments, possibly due to their manipulative accounting treatment, a potentially interesting issue for related accounting research and accounting standard-setters.
\end{abstract}

Keywords: Share-based payments, banking, IFRS2/FASB123R. 


\section{Introduction}

Share-Based Compensation [SBC], particularly employee share options ${ }^{1}$, has expanded significantly since the late 1990s in the US (Murphy, 1999; Mehran and Rosenberg, 2009) and since early 2000 in the EU (Pendleton et al, 2002; European Commission, 2003). One of the main reasons for the widespread use of SBC packages was directly linked to the lax accounting treatment of employee share options in the US (Botosan and Plumlee, 2001) and worldwide (Coulton and Taylor, 2002a; Street and Cereola, 2004; Shiwakoti and Rutherford, 2010). Prior to the mandatory adoption of IFRS2/FAS123R (Share-based Payments), the cost of employee share options was overwhelmingly disclosed in the footnotes ${ }^{2}$ but not recognised in the financial statements of firms. In 2004 and as a response to the most prolonged and controversial debate in the history of accounting standard setting (Johnston, 2006, p.399; Farber et al., 2007), the Financial Accounting Standards Board (FASB) and the International Accounting Standard Boards (IASB) issued FAS123R and IFRS2 (Share-Based Payments), respectively. ${ }^{3}$ Under the newly introduced accounting regime, all SBC schemes ${ }^{4}$ must be recognised as an expense at the fair value, at the grant date, spread over the vesting period.

The IASB/FASB argument to support the mandatory expensing of SBC is that, if SBC expense is not recognised in the income statement, the financial statements will provide ultimately overstated and distorted reported earnings that do not faithfully reflect the underlying economic reality or a 'true and fair' view of companies' financial positions.

Prior to the mandatory adoption of IFRS2/FAS123R, it was argued that expensing SBC would have a material impact on the reported financial performance of companies, causing a deterioration in a variety of performance measures (see Ratliff, 2005). This argument was, indeed, supported by several studies that mainly examined the US (Botosan and Plumlee, 2001) and Australian contexts (Chalmers and Godfrey, 2005). These supporting studies took advantage of data availability of pro-forma disclosure prior to the mandatory recognition regime. Additional concerns have also been raised regarding employees' fear that companies may respond to mandatory imposition of IFRS2/FAS123R by curtailing SBC schemes in their employees' compensation packages to minimise the effect of recognising SBC expense on their financial ratios. Since then, there have been several calls for research to "ascertain the impact of SBC expense recognition on a broader range of firms and for more performance 
indicators" as data becomes available under IFRS2/FAS123R (Street and Cereola, 2004 p. 36).

Schroeder and Schauer (2008) and Shiwakoti and Rutherford (2010) provided initial evidence, using post-FAS123R/IFRS2 adoption data, on the effect of expensing SBC schemes on firms' performance measures in the US and UK contexts, respectively. Yet, the sample period of these studies focused only on the first two years of FAS123R/IFRS2 adoption. Earlier related studies, such as those conducted by Botosan and Plumlee (2001, p.325) and Chalmers and Godfrey (2005), necessitate the need to conduct relevant research over a longer time-span, where the effect of expensing SBC schemes might "become even more economically significant in the near future, potentially doubling over the next three to five years", the period usually required to complete the option life cycle. Firms issue SBC schemes annually, or sometimes in a longer time-span basis, and at a steady or unsteady level; the associated recognised expense of SBC schemes is thus expected to increase gradually over the early years of IFRS2/FAS123R until it becomes, to some extent, stabilised once the life cycle of the first options granted after the mandatory adoption of IFRS2/FAS123R is over ${ }^{5}$. Moreover, the short time-span, not covering the option life cycle, might have also driven the discrepancy in estimating the total effect of expensing SBC on firms' financial performance measures. ${ }^{6}$

This paper identifies, evaluates, and analyses the total impact of mandatory expensing of SBC schemes over a relatively long period of time $(2005-2011)^{7}$ on a set of widely used performance measures for a sample of EU and US banks. Moreover, in this study, we consider all types of share-based payments granted to employees at different levels, including executives.

The EU and the US are internationally active and peer markets that first adopted this standard and the use of SBC is a common practice in their employees' compensation packages. The banking sectors in the EU and US markets are chosen for the purpose of this paper for the following reasons. The use of SBC schemes has become widespread in the banking industry over the last two decades (Chen at al., 2006; Hagendorff and Vallascas, 2011). SBC schemes provide incentives for managers to engage in risk-taking activities. This has been shown to be of particular importance for the banking sector (Chen et al., 2006; Walker, 2009). The significant growth in SBC schemes over these two decades has also been one of the main reasons for the recent capital regulation in banking industry ${ }^{8}$ (Mehran and Rosenberg, 2009). Focusing on the banking sector for the purpose of this paper also responds to the lack of and the need for additional studies on SBC schemes in the banking sector highlighted by earlier 
studies, such as Mehran and Rosenberg (2009). Finally, the homogeneity of the banking industry ${ }^{9}$ provides a stronger setting to control for industry-specific confounding factors.

The findings of this descriptive research suggest that the impact of SBC expense on the selected performance measures, ROE, ROA, EPS and cost to income ratio, is statistically negative. This impact is material, yet modest, for US banks and only for large and high growth EU banks, indicating earlier public concerns and criticisms of the implementation of this standard are largely unsubstantiated. Moreover, the results show that the earlier predictions and employees' fears that firms would curtail SBC schemes to avoid or reduce the mandatorily associated expense came to light after the first option cycle in the post-adoption period was over. Specifically, while banks continue to use SBC, we find a reduction, albeit insignificant, in the recognised SBC expense relative to staff expenses over the period 20092011. Finally, the trend of using cash-settled based payments is marked, possibly due to the issue of accounting manipulation, a potential interesting issue for related accounting research and accounting standard-setters.

The remainder of this paper is subsequently structured as follows. Section 2 reviews earlier related studies. The sample selection and data collection as well as the employed methods are explained in section 3. Section 4 discusses the descriptive characteristics of the sampled banks in this paper. Sections 5 evaluates the impact of recognising SBC expense on the selected performance indicators, and Section 6 analyses the statistical impact of recognising SBC expense on these financial indicators pooled together and using different sets of control. Finally, Section 7 draws conclusions and inferences from the paper's findings and suggests areas to be addressed in future research.

\section{Literature review}

Previous accounting literature has utilised several approaches to examine the large increase in the use of SBC and its impact on firms' market valuation and financial reporting. For example, Carlin and Ford (2006, p. 78) in their study of large listed Australian companies (from 1997-2002) highlighted that the use of share options compensation packages for directors and executives had 'grown substantially' and analysed this growth from a governance perspective. They pointed to increasing evidence that share options schemes were being 'associated with a range of dubious behaviour on the part of executives' (ibid. p78). Indeed, Carlin and Ford conclude that it is not only important to consider the need for 'careful design of incentive contracts' but also to keep a 'careful watch' on the dispersion or concentration of option-based remuneration packages. Brown and Yew (2002), Aboody et al., (2004) and Niu and Xu (2009), among others, have focused on the association between SBC 
expense and market values under alternative accounting treatments. These studies typically conclude that incentive effects of SBC are dominant in firm valuation. Earlier accounting literature has also discussed the detrimental effects on firms' competitiveness and innovation as firms might reduce issuing SBC schemes to avoid decreases in their net income and other related financial performance under the mandatory recognition approach to SBC expense (See Ratliff, 2005).

This paper focuses mainly on the impact of SBC expense on selected financial indicators of reporting entities. The following two subsections, therefore, survey prior studies that investigated the impact of expensing SOBC on companies reported earnings and other related financial indicators prior and after the mandatory adoption of IFRS2/FAS123R.

\subsection{Evidence of impact of IFRS2/FAS123R using pre-adoption data}

Related studies conducted before the adoption of IFRS2/FAS123R, provided evidence supporting the notion that, if the fair value of SBC schemes was treated as an expense, many financial performance indicators would be significantly deteriorated. For instance, Botosan and Plumlee (2001) utilised the pro-forma disclosure on employee stock options for a sample of the top 100 highest earning growth US companies in 1999; the results of their descriptive research show that the mean (median) reduction in diluted EPS and ROA due to stock option expensing would be $22.9 \%$ (14\%) and $22.8 \%$ (13.6\%), respectively. They also predicted doubling of the magnitude of this effect over the following three to five years.

Street and Cereola (2004) further extended Botosan and Plumlee's work by comparing the likely effect of expensing SBC schemes at an international level. Their sample includes 291 non-domestic companies listed in the US but domiciled in other countries. Their findings reveal that the mean (median) reduction in diluted EPS if stock options were expensed in the year ended December 31, 2000, would be $41.19 \%(6.29 \%){ }^{10}$ They also reported that the average pro-forma stock options expense expressed as a percentage of opening stockholder's equity is $14.96 \%$, and the average reduction in net income due to stock option expensing is $38.95 \%$. Their results also indicate that the effect of expensing SBC schemes on the selected firms' performance measures varies significantly across countries.

Chalmers and Godfrey (2005) examined the impact of expensing SBC granted to directors and the five most senior executives, on ROA, ROE, and diluted EPS of 159 Australian firms. They assumed that the vesting period of granted options is three years and the options are granted for the first time on 1 January 2002. They documented that the initial (first year) mean (median) reduction in ROA, ROE and diluted EPS, if firms started to recognise SBC expense in 2002 , would be $3.76 \%(0.34 \%), 13.63 \%(0.41 \%)$ and $13.67 \%(0.40 \%)$, 
respectively. However, once the option cycle was completed and the associated expense had stabilised after three years, the mean (median) reduction in ROA, ROE and, diluted EPS would increase to $11.29 \%(1.01 \%), 40.89 \%$ (1.22\%) and $41 \%(1.21 \%)$, respectively.

\subsection{Evidence of impact of IFRS2/FAS123R using post adoption data:}

Subsequent to the mandatory adoption of the IFRS2/FAS123R in 2004, there have been, as far as we are aware, only two studies that examined the post-adoption effect of IFRS2/FAS123R on firms' financial indicators. The first study was conducted by Schroeder and Schauer (2008). They examined the actual effect of expensing SBC schemes for a sample of 90 US firms with fiscal year-end on 30 June 2006. Their findings suggest that expensing SBC schemes in the first year of the mandatory adoption of FAS123R does not result in a material effect on companies' total revenues. Schroeder and Schauer (2008) also reported that the weighted average effect on net income (loss) due to SBC expensing was material, $15.91 \%(33.55 \%)$. Pointedly, they claim that the effect of SFAS123R tended to be more material for smaller sized companies. ${ }^{11}$

Shiwakoti and Rutherford (2010) examined the impact of IFRS2 adoption on a set of selected performance measures for a sample of 266 UK firms over the period 2004 to 2006, where 2004 falls before the adoption and 2005 and 2006 fall afterwards. Their findings reveal that the effect of IFRS2 in the UK is only modest. They reported, in 2004, the mean (median) reduction in ROA, ROE, EPS due to expensing of SBC schemes was not material at the 5\% significance level. However, in 2005 and 2006, the reduction in the selected performance measures as a result of expensing SBC schemes was slightly above 5\%, implying a modest impact. Shiwakoti and Rutherford (ibid) reported that the impact varies across sectors; and it is slightly higher for the larger sized and more rapidly growing firms.

Seethamraju and Zach (2003) argue that companies may respond to IFRS2/FAS123R by reducing SBC schemes to avoid the negative effect of the recognised SBC expense on their financial ratios. Indeed, following the transition from the voluntary to the mandatory approach for expensing SBC under FAS12R, US firms reduced the proportion of stock options to executives' total compensation (Brown and Lee, 2011), and the number of options granted across all levels of rank and file employees (Choudhary, 2008).

The existing literature provides insight into the reduction in firms' performance measures as a result of the mandatory adoption of FAS123R/IFRS2, yet with a wide range in the reported reduction as identified above. Overestimated or underestimated results could be driven by several factors that might explain this variation in the reported reduction. First, IFRS2/FAS123R applies not only to stock options but also to other types of share-based 
payments, such as share appreciation rights, granted to all employees (i.e., not only the top executives). Second, the variation in the time-span covered in earlier studies also might influence the magnitude of the reduction in firms' selected performance measures. While most of earlier related studies focused on one-year data to estimate the average effect of SBC expensing on selected performance measures, Shiwakoti and Rutherford (2010) covered three years [2004-206], including two years that fall in the post IFRS2 regime [2005-2006]. To capture the likely impact of IFRS2/FAS123R on the selected performance measures, at least a three to five-year sample period is warranted (Botosan and Plumlee, 2001). This is the period usually required to complete the life cycle of the first options granted after IFRS2/FAS123R and after which SBC expense will stop gradually increasing and is more likely to stabilise, assuming firms grant SBC steadily on an annual basis. Third, the sample in the majority of related studies conducted before the mandatory adoption of IFRS2/FAS123R were limited to the voluntarily disclosed data when carrying out their analysis. This may result in a selection bias in their studies as firms that choose to adopt accounting standards voluntarily may have innate characteristics affecting their adoption decision, and they might seek to achieve some hypothesised economic consequences (Sodestrom and Sun, 2007).

\section{Method and sampling}

\subsection{Methods}

All the performance measures utilised in earlier studies, [ROE] (Chalmers and Godfrey, 2005), [ROA, Diluted EPS] (Botosan and Plumlee, 2001), [SBC expense relative to opening shareholders' equity] (Street and Cereola, 2004), [profit (loss) before tax] (Schroeder and Schauer, 2008) in addition to a widely used performance measure in banking industry (cost to income ratio $[\mathrm{CIR}])^{12}$, have been employed in this paper. All the selected performance measures are calculated with and without SBC expense. The effect of SBC expense on a measure in percentage is calculated as follows: ratio adjusted for SBC expense (i.e., the selected ratio is calculated after deducting SBC expense) minus reported ratio, and the difference is divided by the reported ratio. The effect of the IFRS2/FAS123R on the selected financial performance measures is assessed by utilising the materiality thresholds used in prior research and materiality statistical tests. Differentiating between statistical and practical significance is a matter of importance. Small numerical differences measured in percentage terms can be regarded as statistically significant, yet these differences might be immaterial from a practical standpoint.

Following previous literature, we use the 5\% materiality threshold to assess the impact of expensing SBC on ROA, ROE, Diluted EPS, while the corresponding materiality thresholds 
to test the impact on opening shareholders' equity and the cost to income ratio are $0.5 \%$ and $2 \%$, respectively. ${ }^{13}$ To investigate the significance of the effect of SBC expensing under IFRS2/FAS123R on the selected performance measures statistically, we use the nonparametric Wilcoxon-Mann-Whitney (U) test/Wilcoxon signed-rank (WSR) test along with their comparable parametric $\mathrm{T}$ test for robustness check. These tests allow us to examine whether the effect of expensing SBC on the selected performance measures is statistically significant and whether the median and the mean of this effect significantly vary between EU and US banks. To complement our analysis, we use the Kruskal-Wallis test along with the one-way analysis of variance (ANOVA) as a robustness check to examine whether the effect of IFRS2/FAS123R on the selected performance measures significantly varies within each block of EU and US banks after controlling for some bank-specific characteristics (size, opportunity growth rate, and the variation in banking activities/structure). All figures are reported in US currency (\$) using the exchange rate at each closing period.

\subsection{Sampling and data collection}

The data on the recognised expense of SBC schemes is hand-collected from the published annual reports of a sample of listed Commercial Banks (CBs) and Bank-holding Companies (BHCs) in the EU and US. ${ }^{14}$ The sample banks, in addition to accounting and market variables over the period 2004-2011 ${ }^{15}$, are extracted from the BankScope database.

Banks included in our data set are required to satisfy certain criteria. First, the average assets of banks over the study period should be over $\$ 500$ million. ${ }^{16}$ Second, for US banks, they should be constituents of the S\&P Composite 1500. This resulted in a sample of 90 BHCs and $1 \mathrm{CBs}$. To increase the representation of US commercial banks in our sample, 19 banks classified as listed US commercial banks (not listed in the S\&P 1500 but elsewhere in the US) in the BankScope database and with over $\$ 500$ million on average total assets over the selected period, were added to our sample. This yields an initial sample of 90 BHCs and 20 CBs listed in the US, as well as $28 \mathrm{BHCs}$ and $58 \mathrm{CBs}$ listed in the EU.

To filter out BHCs that are not mainly engaged in traditional banking activities (i.e., deposit taking and loan making activities), EU and US BHCs should have more than $25 \%$ net loan to total assets on average over the study period to be included in our sample. For EU listed banks, they should also have published their annual reports in English. Furthermore, banks should have incorporated the expensing of SBC in their annual reports for at least three years over the study period. ${ }^{17}$ Finally, banks should have the required accounting and financial market data in the BankScope database over the study period. Table (1) summarises the final sample of $100 \mathrm{BHCs}$ and $45 \mathrm{CBs}$ of which $13 \mathrm{BHCs}$ and $30 \mathrm{CBs}$ are listed in the EU. This 
final sample produces a total of 1,010 bank-year observations of which 308 are from EU banks. Table (1, panel B) also shows that around $60 \%$ of our EU bank-year observations (i.e.,180 out of 308 observations) are obtained from banks listed in the UK, Italy, Germany, France, Netherland, and Spain.

Insert Table 1: Sample selection, countries and observations

\section{Descriptive statistics}

Table (2) identifies the descriptive characteristics of the sampled banks. It highlights various proxies of size, such as market value, total assets, opening value of shareholders' equity, and employee numbers. The banks included in the sample vary in size. The average total assets of banks in our sample is $\$ 277$ billion. The average market capitalisation over the study period is $\$ 14.6$ billion ( $\$ 27.4$ billion and $\$ 8.8$ billion for EU and US banks, respectively).

Insert Table (2): Descriptive statistics.

Table (2) shows that the average recognised expense of SBC schemes in EU and US banks over the study period is $\$ 166.1$ million and $\$ 87.1$ million, respectively, with a median of $\$ 13.9$ million and \$3.7 million, respectively. Because of the size differences, the larger absolute recognised expense of SBC schemes in EU banks does not necessarily mean that they use SBC schemes more than US banks. The ratio of SBC expense relative to staff costs indicates that US banks seem to use SBC schemes in their employees' compensation packages more than twice as much as that used in EU banks. The mean (median) of SBC expense relative to staff costs over the studied period is $4.5 \%$ (3.2\%) for US banks compared to $1.9 \%(1.3 \%)$ for EU banks. As a further analysis, we express in Table (3) the recognised expense of SBC schemes as a percentage of several variables used in prior studies (Botosan and Plumlee, 2001; Street and Cereola, 2004; Chalmers and Godfrey, 2005; Schroeder and Schauer, 2008; Shiwakoti and Rutherford, 2010).

Insert Table (3): SBC expense relative to selected key variables.

Table (3) shows that the mean (median) of recognised SBC expense represents $0.05 \%$ $(0.03 \%)$ of banks' total assets over the sample period [0.02\% $(0.01 \%)$ and $0.06 \%(0.04 \%)$ for EU and US banks, respectively]. That is, the recognised expense of SBC schemes relative to banks' total assets is immaterial using the materiality threshold of $0.5 \%$ suggested in prior studies (Chalmers and Godfrey, 2005; Shiwakoti and Rutherford, 2010). Again, this descriptive evidence suggests that US banks use SBC schemes more than EU banks.

Table (3) also shows that mean (median) of SBC expense represents on average 5.13\% $(2.76 \%)$ of pre-tax profit $^{18}$ and $7.98 \%(3.36 \%)$ of pre-tax loss ${ }^{19}$ reported in our selected 
sample over the study period. ${ }^{20}$ It also shows that average percentage of SBC expense on pretax profits slightly exceeds the 5\% materiality level for US banks [6.12\%] and falls below the materiality level for EU banks [3.02\%]. This suggests that the ratio of SBC expense relative to pre-tax profit is twofold in the US compared to that in the EU.

In terms of the average recognised SBC expense relative to pre-tax loss, it is material in both regions $(6.22 \%$ and $8.57 \%$ for EU and US banks, respectively). These statistics are in line with those of Schroeder and Schauer (2008), who documented that companies reporting net losses had material amount of SBC expense. That is, the average recognised SBC expense relative to pre-tax loss appear to be higher than the corresponding percentage using pre-tax profit. Finally, table (3) shows that the mean (median) of recognised expense of SBC schemes represents $0.61 \%$ (42\%) of our selected banks' opening shareholders' equity over the study period. It also shows the mean slightly exceeds the $0.5 \%$ materiality level for EU and US banks [0.51\% and $0.66 \%$, for EU and US banks, respectively].

\section{Impact of option expensing on ROE, Diluted EPS, and CIR}

Table (4) presents the effect of the mandatory recognition of SBC expense under IFRS2/FAS123R on each of the following selected performance measures, the ROE, Diluted EPS, ${ }^{21}$ and CIR over the period under study, along with the magnitude of SBC expense relative to opening shareholders' equity.

Insert Table 4: $(A)(B)(C)$ : The effect of expensing SBC schemes on selected financial measures in EU and US

Table 4 (A) shows the average impact of the mandatory adoption of IFRS2/FAS123R on the selected performance measures over the post-IFRS2 adoption period for EU and US banks. The average impact falls a little below the corresponding materiality thresholds for ROE, DEPS, and CIR, while it is around the materiality thresholds for SBC expense as a percentage of opening shareholders' equity. Table 4 (A) also shows that the average impact of FAS123R for US banks falls above the materiality thresholds for all the selected performance measures, and its magnitude is more than twice of that in the EU sample.

Table 4 (B) (C) shows that, except for CIR in EU, the impact of expensing SBC schemes on the selected performance measures in the pre-adoption period (2004 for the EU sample and 2005 for the US sample) is greater than that in the first year of IFRS2/FAS123R adoption (2005 for the EU sample and 2006 for the US sample). The reason for such a trend could be that banks accelerated the vesting conditions of SBC schemes to avoid recognising the associated expense of standing unvested grants using the fair value approach in the first-year of adoption (Choudhary et al., 2009). ${ }^{22}$ Table 4 (B) also shows, until 2008, the impact of expensing SBC schemes on the selected performance measure for EU banks are less than 
their corresponding materiality thresholds, indicating immaterial impact on the performance indicators under investigation. However, this impact in 2009 slightly exceeds the materiality level in the EU sample $(5.09 \%, 6.60 \%$ and $0.55 \%$ for ROE, Diluted EPS and SBC expense relative to opening shareholder equity, respectively), indicating a modest effect over this year on the selected performance indicators. In the US sample, the average effect of expensing SBC schemes on ROE (14.4\%) and Diluted EPS (11.79\%) is also slightly higher in 2009 compared to that in previous years. This position (with a gradually increasing effect) can be due to the settlement that took place at the end period of the option life cycle, which usually takes from three to five years if a bank issue SBC schemes annually (Botosan and Plumlee, 2001).

However, the effect of SBC expense did not stabilise afterwards. Rather, it decreased dramatically in 2010 compared to that in 2009 in both samples with the exception of CIR in EU banks. This evidence is consistent with earlier predictions (e.g., Seethamraju and Zach, 2003) that companies may respond to mandatory imposition of IFRS2/FAS123R by curtailing SBC schemes to avoid the effect of SBC expense recognition on their financial ratios. In 2010, the impact on most of the selected performance measures returned to a level less than the average impact over the study period for the EU and the US banks, respectively. In 2011, the impact of SBC expense on the selected performance measures grew in the EU sample again compared with that in the other years. In the US, the impact in 2010 and 2011 slightly went down compared to the average impact over the study period. Such a decline might imply the curtailment of SBC schemes by firms to avoid the effect of SBC expense recognition on their financial ratios starting to appear after completing the first options cycle in the post-adoption period. This is also apparent from the slight decline in the percentage of SBC expense relative to opening shareholders' equity in 2010 and in 2011 for both samples. This issue is investigated in more depth in section 6 and by using statistical tests.

\section{Assessing the statistical impact of SBC expense on selected performance measures}

This section explores the significance of the effect of IFRS2/FAS123R on banks' selected performance measures using statistical tests in lieu of materiality thresholds.

Insert table (5) A: Selected performance measures with and without adjustment for SBC expense Insert table (5) B: The difference in the change of the selected performance measures exclusively due to the introduction of IFRS2/FAS123R

Table 5 (A) shows the significance of the mean (median) differences between the selected reported and adjusted ratios for SBC expense using statistical tests over the pre- and postIFRS2/FAS123R implementation years. Both WSR and T tests suggest that all differences between reported and adjusted ratios are statistically significant, indicating a material 
influence on the selected performance measures. The findings support the IASB/FASB argument that, if SBC expense is not recognised in the income statement, the financial statements will provide overstated and distorted reported earnings that did not faithfully reflect the underlying economic reality or a 'true and fair' view of companies' financial positions.

As an additional analysis, we explore how the mandatory expensing of SBC schemes affects the changes in the selected financial indicators, especially in the first year of IFRS2/FAS123R adoption. Table 5 (B) highlights the average difference in the change $(\Delta)$ of the selected performance measures over the period, 2004-2005 for EU banks and 2005-2006 for US banks, exclusively due to the mandatory introduction of IFRS2/FAS123R. It shows a reduction in the change of these measures, except when Diluted EPS falls below their related corresponding materiality thresholds for EU banks. For US banks, the reduction in the change of almost all selected performance measures falls around the materiality thresholds used in earlier studies, indicating a modest impact compared to that predicted by prior literature (e.g., Botosan and Plumlee, 2001; Street and Cereola, 2004; Chalmers and Godfrey, 2005). Also, both $\mathrm{T}$ and WSR tests indicate that this reduction in the change of the selected measures is statistically significant.

To further investigate the trend of SBC expense in absolute values and relative to total staff expenses, we divide our study period into four distinctive periods: i) Pre IFRS2/FAS123R adoption, 2004 and 2005 for EU and US banks, respectively; ii) pre-global financial crisis: from the first year of IFRS2/FAS123R adoption until 2007; iii) the global financial crisis in 2008; iv) post-global financial crisis, 2009-2011. Specifically, a comparison between the preadoption and post-adoption period, pre-adoption period and pre-global financial crisis, and over the three phases of the post-adoption period (i.e. pre-global financial crisis, the global financial crisis and post-global financial crisis) has been also conducted.

Insert table (6): Comparison of SBC expense and SBC expense relative to staff expenses over the studied period using $T$ and $U$ test:

The results from table (6) indicate, for both EU and US banks, the mean (median) of SBC expense in absolute values over the pre-adoption period [120.5(16.35) and 65.43(4.56) for EU and US banks, respectively] did not vary significantly from that of post-adoption period at the 5\% level. Table (6) also shows that the changes in the mean of SBC expense in absolute values across the compared periods are redundant and insignificant. However, relative to total staff expenses, SBC expense significantly decreased for US banks when we 
compared the pre-adoption and post-adoption period, and pre-adoption period and the precrisis period, respectively, at the 5\% level. This result might indicate that accelerating the vesting conditions of SBC schemes to avoid recognising the associated expense of standing unvested grants in the first-year of adoption is more apparent for US banks compared with that of EU banks. Table (6) also shows that a decrease, yet insignificant, in SBC expense relative to total staff expenses started to appear in the post crisis period (2009-2011) in both samples. This suggests that the full impact of the early predicted curtailment in using SBC schemes following the mandatory adoption of IFRS2/FAS123R became apparent after the first option life cycle in the post-adoption period was over. That is, employees' fear that companies would curtail SBC schemes subsequent to the mandatory adoption of IFRS2/FAS123R started to reflect its effect on the recognised SBC expense after finishing the first post-adoption option life cycle. Finally, table (6) shows that SBC expense relative to total staff expenses significantly decreases in 2008 compared to pre-crisis period in the EU sample. Interestingly, one potential reason behind this significant decrease in SBC expense in 2008, particularly in the EU sample could be the cash-settled based payments ${ }^{23}$ expense.

\section{Insert Fig. 1 cash-settled based payments in EU and US banks}

Figure (1) shows that in 2008, the average cash-settled based payments expense dropped dramatically, particularly in the EU sample. Given the negative effect of the crisis on the majority of accounting and market performance indicators, this reduction might suggest that bank management exploited the opportunity to obtain advantages from the accounting requirements of the standard for cash-settled based payments. Both IFRS2 and FAS123R allow companies to modify the fair value determined at grant date for cash-settled grants at each reporting period date and on settlement. Firms can even reverse cash-settled payments expense recognised in previous years when the vesting conditions of corresponded cashsettled based compensation schemes in a given year are not met or less likely to be met before the expiry date of these schemes. The stated SBC expense because of the reversed expense of cash-settled based payments in a given year could even become negative. We have in this paper 11 observations with negative SBC expense. This accounting flexibility in the standard along with the negative effect of the crisis on the given performance vesting conditions may have helped managers to increase the reported earnings or lessen the reported losses in 2008. More pointedly, banks' management also may have modified (the earlier specified) onerous vesting conditions to a new more realistic basis that is easier to attain in the near future, more likely in 2009. This also might explain the dramatic increase in cashsettled based expense in 2009, particularly in the EU sample. Finally, figure (1) also shows that banks in both samples have gradually moved towards using cash-settled based payments 
over the study period. The mean of cash-settled based payments expense in US banks rose from less than \$1 million in 2005 to $\$ 9$ million in 2011, whereas, in EU banks, it increased from $\$ 9.55$ million in 2004 to $\$ 18$ million in 2011. One of the main reasons for such a movement towards cash-settled based payments, again, might be that banks can modify the fair value of this type of SBC schemes at each reporting period date and on settlement. However, for equity-settled based payments, firms are allowed to modify the fair value calculated at the grant date, only if the vesting conditions of option grants are nonperformance-based and they are more likely to forfeit. This seems to give banks' managers an opportunity to obtain advantages from the accounting requirement of cash-settled based payments under IFRS2. Therefore, cash-settled based payments might be used for the purpose of earnings management, among other things, an issue that needs further consideration by IASB and other standard setters. This also suggests that a "carful watch" on the structure of SBC payments is another important element of governance oversight (Carlin and Ford, 2006: p82).

\subsection{Size, opportunity growth and variation in banking activities and the impact of SBC expense on selected performance measures}

Table (7) shows whether the impact of IFRS2/FAS123R on the selected performance measures varies according to banks' size and opportunity growth rate. For both the EU and US samples, banks have been divided into four sub-samples, based on the quartiles of banks' average total assets (a proxy for size) and market to book value (a proxy for opportunity growth rate). The Kruskal-Wallis test and its comparative one-way analysis of variance (ANOVA) suggest that the impact of the mandatory adoption of IFRS2/FAS123R on the selected performance measures varies significantly across banks according to their size and opportunity growth rate within each of the EU and US samples. Table (7) also shows that the material effect of mandatory recognition regime of IFRS2/FAS123R in both samples is noticeably confined to larger banks; the larger the bank, the more significant the impact. This might be intuitively due to the fact that the larger the banks, the more heavily they use SBC schemes. The number of granted SBC schemes is a major factor that plays a key role in determining the recognised expense of SBC. Earlier studies, such as Core and Guay (2001), Coulton and Taylor (2002b), Melissa (2004) and Walker (2010), have found evidence that firm size has a positive and significant relationship with the use of SBC schemes. Another explanation for this finding is that employee share option-based compensations are form of "rent extraction" used by CEOs of large firms (Coulton and Taylor, 2002b). Needless to say, 
vesting terms and conditions also play a key role in determining the recognised expense of SBC schemes. Besides, the level of operational complexity of large banks is far greater than that of small banks (Avraham, et al., 2012). As such, vesting conditions could also be more relaxed in large banks due to their greater complexity. Relaxing the vesting conditions of SBC schemes increases their fair value and therefore the associated SBC expense as these schemes will become more likely to vest. This scenario might contribute to the reason the effect of expensing SBC on large banks' performance measures are more material. This raises an interesting issue to be investigated by future research interested in the structure and motivational aspects of SBC contracts and other related corporate governance issues in the banking industry.

\section{Insert table (7): The impact of SBC expense on selected financial measures (Size and Growth Effect)}

Walker (2010, p263) evaluated the adoption of CEO performance-based compensation packages by using a sample of high and low growth firms' in Australia. She identified that the use of equity-based compensation (as a component of CEO overall compensation packages) is 'positively associated with firm size and growth options. Consistent with her results, Table (7) shows that the impact of mandatory recognition regime of IFRS2/FAS123R on the selected performance measures of each of the EU and US samples is higher for high growth banks (the $3^{\text {rd }}$ and $4^{\text {th }} \mathrm{Q}$ ). The result is also in line with studies conducted in the US by Botosan and Plumlee (2001) and in the UK by Shiwakoti and Rutherford (2010).

The results of $U$ test and its comparative T tests in table (7) also indicate that the impact of IFRS2/FAS123R on most banks' selected performance measures after controlling for banks' size and opportunity growth rate is significantly higher for US banks. The mean (median) impact of FAS123R on the selected measures is material for US banks with the effect becoming higher for larger banks. ${ }^{24}$ In the EU, the average impact of IFRS2 on the selected performance measures is only materially confined to large banks (the fourth quarter).

Finally, we investigate whether the impact of SBC expensing on the selected performance measures also varies according to banks' organisational structure (classification to commercial and bank-holding companies) ${ }^{25}$ and to the variation in the level of traditional banking activities of BHCs. The motivation for this analysis is that the impact of IFRS2/FAS123R might vary with the diversification of bank activities. Over the last few decades, there has been a notable movement of banks' activities towards engaging more in non-traditional banking activities, such as securities underwriting and trading and selling insurance products (Stiroh, 2004; Avraham et al., 2012). In this context, Becher et al. (2005) documented an increase in the use of SBC schemes following the deregulation of banking 
industry. Table (8) shows that the effect of the recognised SBC expense on the selected performance measure varies significantly between BHCs and CBs within each block separately and it seems to be the highest for US CBs. It also shows that the impact of IFRS2/FAS123R on the majority of banks' selected performance measures is significantly higher for US banks compared to EU banks after controlling for banks' organisational structure.

Interestingly, the effect for EU banks is below the corresponding materiality thresholds for the selected performance measures, yet it seems to be higher for banks classified as BHCs. To further investigate this issue, EU and US BHCs have been divided into two sub-samples, based on the median of banks' average net loan to total assets as a proxy for the variation in traditional banking activities. The results of $\mathrm{U}$ and the $\mathrm{T}$ tests indicate that the effect of FAS123R on the selected performance measures for the US BHCs does not vary significantly after controlling for variation in traditional banking activities. For example, SBC expense relative to opening shareholders' equity does not vary significantly among all US sub-groups, yet it is still around its traditional materiality threshold in all sub-groups. This suggests that the effect of expensing SBC schemes in the US sample is material in all sub-groups, irrespective to their organisational structure and the degree of variation in traditional banking activities. By contrast, the effect of IFRS2 on the selected performance measures is significantly higher for the EU BHCs that engage more in non-traditional banking activities. It is worth mentioning that diversified banking activities also imply a complex banking portfolio and therefore a greater tendency to use SBC schemes (Pendleton et al, 2002).

\subsection{Additional Analysis}

We also extend our analysis by controlling for the legal tradition under which the samplebanks operate. We divided our sampled banks into banks domiciled in codified-law countries and banks domiciled in common-law countries. For each subsample, we also identified the impact of expensing SBC schemes after controlling for different characteristics of banks, banks' size, and banks' growth rate, along with banks' operational structure or differences in banking activities. Earlier studies suggested that the agency problem and information asymmetry is more apparent in reporting environment where the institutional business environment and corporate governance typically focuses on firm's shareholders because of the lack in the shareholder-manager direct contact (See Ball et al., 2000). As such, to alleviate the agency cost, agents, particularly top managements, in common-law countries, such as the US, UK, and Ireland, tend to rely more on SBC schemes in comparison to other countries. Whereas, in countries with codified legal tradition such as Germany, agents such as employees and managers are influential stakeholders whose pay-out is internalised to a 
certain extent with other stakeholders. Furthermore, the advantages of closer shareholdermanager contact in codified-law countries, making it less likely to depend heavily on SBC schemes. The impact of expensing SBC, therefore, is expected to be more apparent in common law countries compared to their codified law counterparts. Consistent with this view, our un-tabulated results suggest that the average effect of IFRS2/FAS123R falls above the materiality thresholds for all the selected performance measures only in banks that operate in common-law countries, and it is twice as much as for those operating in codified law countries. Our results are also robust after controlling for banks' size, growth opportunities, and variations in banking activities.

\section{Conclusion and future research:}

This paper identifies, evaluates, and analyses the total impact of mandatory expensing of SBC schemes under IFRS2/FAS123R on a selected set of performance measures for a sample of EU and US banks, using pre and post-adoption data that covers a longer study period relative to prior related literature. The present descriptive research shows that, through time, the accounting treatment of SBC schemes following the mandatory adoption of IFRS2/FAS123R has resulted in a statistically significant negative impact on the selected performance measures, ROE, ROA, EPS and cost to income ratio. This result supports the IASB/FASB argument that if SBC expense is not recognised in the income statement, the financial statements will provide overstated and distorted reported earnings that did not faithfully reflect the underlying economic reality or a 'true and fair' view of companies'. Furthermore, the impact of the mandatory adoption of IFRS2/FAS123R on the selected performance measures seems to be material for the sample of US banks, and only for large and high opportunity growth banks in the EU. The material impact for US banks and for large and high opportunity growth EU banks is, yet still modest, indicating that earlier public concerns and criticisms of the implementation of this standard are largely unsubstantiated.

In addition, the findings show that earlier predictions and employees' fears that firms would curtail SBC schemes to avoid or reduce the mandatorily associated expense, came to light after the first option life cycle in the post-adoption period was over. Yet the decrease is insignificant. This suggests that banks continue to use SBC but there is a reduction, albeit insignificant, in the recognised SBC expense over the period 2009-2011. Finally, the findings also show a considerable movement towards using cash-settled based payments, possibly due to their flexible accounting treatment, a potential important issue for related accounting research and accounting standard-setters. 
Findings of this paper can be informative to standard-setters as we put the impact of adoption of a highly controversial accounting standard into a global context and bench-mark two internationally active and peer markets that first adopted this standard. Future studies can provide further insight on whether the effects of IFRS2/FAS123 on financial performance measures vary across other industries and other countries including emerging countries that adopted IFRS2. Future studies might also want to extend the sample period to post 2011. However, based on the economic stability throughout that period ${ }^{26}$ and the lack of any substantive changes to either banking requirements, such as Basel or relevant accounting standards, it is our belief that any such research would produce consistent finding to our own. Another interesting issue raised in this paper is whether the complexity of banks' operations influences the level of vesting conditions of SBC schemes. This issue might be of interest to researchers interested in the structure and motivational aspects of share-based compensation contracts and other related corporate governance issues. Furthermore, the response of companies in restructuring the compensation arrangements because of the adoption of IFRS2/FAS123R is another interesting issue for future research. Finally, our findings are a matter of importance for financial reporting users concerned with the extent of the changes in the selected financial indicators that are widely used in different contractual specifications, such as variable compensation contracts and in estimating firms' value.

\section{Notes:}

1- Employee share options are the most common component of SBC packages. Hall and Murphy (2003, p. 2) defined employee stock options (ESOs) as "contracts that give the employee the right to buy a share of stock at a pre-specified "exercise" price for a pre-specified term."

2- Financial reporting regulations in much of Europe at that time varied from country to country, but generally, they did not require SBC schemes to be treated as an expense, nor was there a pro-forma disclosure requirement. For example, some EU countries such as the UK, only recommended firms to disclose details of shares granted to each director in the annual reports (Shiwakoti and Rutherford, 2010). In Italy and France, the disclosure was only limited to quantitative information about the number of share options and their variations during the year, without disclosing their fair value (See Corbella and Florio, 2010; Goh et al., 2016). It seems, in the EU, more emphasis was given to openness and disclosure of information than how this information would be accounted for. As a result, unlike in the US, not even pro forma statements by way of notes to the financial statements were required in the EU.

3- On 19th February 2004, the IASB released IFRS2 (Share-based payments), which was first applied to accounting periods starting 1st January 2005. Similarly, the FASB released SFAS 123R (Share-based payments) in December 2004, as one of the earlier accounting standards that has been closely converged with IFRS. The standard was first applied to accounting periods ending in 2006

4- This includes share options, share purchase and long-term plans and other equity awards, as well as cash-settled based payments where the cash payments depend on the share price.

5- As the fair value of all share option schemes awarded after November 2002 with first vesting after 1 January 2005 were required under IFRS2 to be included in the charge to profits, Choudhary et al., (2009) provided evidence that firms accelerated the vesting condition of SOBC grants to avoid recognising expense for standing unvested grants using the fair value approach in the first-year adoption in their financial reporting

6- There has been a wide variation in estimating the average reduction in the reported earnings as result of expensing SBC schemes. For example, Sir David Tweedie (2002), the first chair of the IASB, estimated that the average reduction in the reported earnings of the top 500 US companies would be between $8 \%$ and $12 \%$, if IFRS2 had been adopted in 
2002[Available at http://www.frc.gov.au/speeches/tweedie_speech.asp]. Apostolou and Crumbley (2005) estimated that the expensing of SBC in some companies such as Yahoo and Adobe would negatively affect their diluted earnings per share (EPS) reported in 2003 by $86 \%$ and 70\%, respectively. The average reduction in Diluted EPS, for example, as estimated by earlier related studies, range from 22.9\% (Botosan and Plumlee, 2001) to $41.19 \%$ (Street and Cereola, 2004). It is also worth noting that these previous studies were conducted based on samples comprising firms from a wide spectrum of industries which might influence their results. Each industry has its own characteristics that could influence the potential effect of recognising share based payments expense on the key financial ratios.

7- We believe that the period 2005-2011 is enough to capture the likely impact of IFRS2/FAS123R on the selected performance measures as it covers the warranted three to five-year sample period, the period usually required to complete the option cycle and after which SOB expense is more likely to stabilise assuming that firms grant SBC on an annual basis.

8- In the US, for example, the Congressional Emergency Economic Stabilization Act was established in 2008 to limit financial institutions' tendency to offer share-based incentives in order to reduce the probability of "unnecessary and excessive risks that threaten their equity values.

9- The banking industry has its unique characteristics that differ from those of other business sectors in terms of regulatory restrictions and their commensurate duties and responsibilities to depositors and investors. EU banks, for example are subject to rules set by regulatory bodies, such as the European Banking Committee and the European Banking Authority operated by the European Commission, and professional bodies, such as the European Banks Federation among others. These rules and regulations generally attempt to promote the single market particularly in the banking sector.

10- The average impact by country was as follows: Australia $7.92 \%$, Canada 59.34\%, France 64.38\%, Germany $5.63 \%$, Ireland $61.38 \%$, Japan $2.80 \%$, and the U.K. $22.68 \%$.

11- There is no evidence in Schroeder and Schauer's (2008) study about the nature of the sectors these firms belong to, where earlier studies predict the effect might vary extensively from one business sector to another (Street and Cereola, 2004, p. 33; Chalmers and Godfrey, 2005, p. 166).

12- The well-established CIR has been used recently by academics and practitioners as a core measure to assess banks' cost efficiency (See Hess and Francis, 2004, Beccalli et. al, 2006). According to a survey conducted by the ABA Banking Journal, an industrial journal published by the American Bankers Association, publicly traded banks and equity analysts consider this ratio an important benchmark of cost efficiency (Cocheo, 2000). Given the intuitive appeal of CIR as a proxy for cost efficiency, it is also relevant to examine the effect of IFRS2/FAS123R adoption on this ratio.

13- Utilising an appropriate 'cut-off' for testing the traditional materiality threshold is a subjective undertaking, ranging from approximately $0.5 \%$ to $50 \%$ (Vance, 2011).

14- CBs and BHCs are the main dominant structure of commercial banking industry in both sides of the Atlantic (Avraham, et al., 2012; ECB, 2013). Over the last few decades there has been a notable movement of banks' activities towards engaging more in non-traditional banking activities such as securities underwriting and trading and selling insurance products (Stiroh, 2004; Avraham et al., 2012). Changes in the regulatory environment is one of the main reasons that banks registered as Bank holding companies (BHCs) are allowed to expand their traditional banking activities, to a certain limit, and engage directly or indirectly in other related banking activities (Aharony and Swary 1981, Avraham et al., 2012). In this paper, we also assess to what extent the impact of IFRS2/FAS123R on banks' performance measures vary between CBs and BHCs.

15- The pre-adoption year for the US sample is 2005, whereas it is 2004 for the EU sample because the mandatory IFRS2 was first applied to accounting periods starting 1st January 2005, whereas FAS123 commenced on reporting periods beginning after June 15, 2005, which implies that financial reporting statements for 2006 is the first adoption year. Preadoption period data is limited to one year due to the limited available disclosure in EU banks. In particular, SBC expense have been hand-collected from the first-year adoption comparative figures on expensing SBC packages in EU banks. In US banks, the pre-adoption data has been hand-collected from the pro forma disclosure in the footnotes attached to banks' financial statements.

16- Setting the threshold of $\$ 500$ million in average total assets is based on two reasons: U.S. BHCs are required to fill the FR Y-9C report, the most widely requested and reviewed report at the holding company level, if their total assets are over $\$ 500$ million. This threshold is expected to increase the likelihood of finding comprehensive disclosure by our initial sampled EU and US banks about the recognised expense of SBC schemes as required by IFRS2/FAS123R. This threshold also allows us to avoid over-representing very small banks in our sample.

17- SBC schemes, particularly share options, usually need three to five years to complete their life cycle after which the associated expense is expected to stabilise especially for firms that use SBC schemes annually in a steady level (Botosan and Plumlee, 2001).

18- The recognised expense of SBC packages relative to pre-tax profit exceeded the 5\% of materiality threshold in $29.1 \%$ of our observations of banks that reported pre-tax profit (16.4\% and 35.07\% of the EU and US sample respectively) [untabulated result] 
19- The recognised expense of SBC schemes relative to pre-tax losses exceeded the 5\% of materiality threshold in $40.83 \%$ of our 120 observations of banks that reported pre-tax loss (30\% and $44.44 \%$ of the EU and US sample respectively) [untabulated result]

20- Over the post IFRS2/AS123R adoption period, there are 763(120) bank-year observations with pre-tax profits (losses). Furthermore, one Irish bank would have reported a pre-tax profit rather than pre-tax loss if SBC expense was not recognised as an expense in 2008. Two US banks were similarly in this position in 2010 and 2011.

21- The impact of SBC expense on ROE in percentage mirrors the impact observed on ROA; therefore we did not report the effect of SBC expense on ROA. Botosan and Plumlee (2001) also reported the impact of stock option expense observed on diluted EPS and ROA mirrors the impact on total net income, basic EPS, and E/P ratios in parentage.

22- IFRS2 requires all equity-settled payments awarded after 7th November 2002 and vested after the effective date of IFRS2 should be accounted for using the fair value method; therefore, data concerning shares granted after 7th November 2002 as well as not fully vested at the beginning of 2005 were collected as well.

23- Cash-settled based payments, one type of SBC schemes, arise in transactions where a company receives services from its employees and incurs a liability to transfer cash, based on the value of the company shares as consideration. An example of liability awards is the grant of share appreciation rights (SARs) to employees, which entitle them to future cash payments based on the increase in the company's share price.

24- The average effect of expensing SBC on the selected performance measures seems to be the highest for 1st quartile of US banks. However, this is due to some extreme observations. The median effect also suggests the larger the bank, the higher the effect.

25- We used BankScope's classification. 
26- We have considered the changes in the economic environment of the countries under study over the period from 2011 (i.e. the end of our study period) to 2017. We used three macro-economic variables: inflation, interest rate and GDP growth. With the exception of Greece and Ireland, the economic environment in the countries under study is relatively stable. Therefore, we repeat our main analysis after excluding the observations from Greece and Ireland, and our results still hold.

\section{New page}

\section{References:}

Aharony, J. and Swary, I., "The effects of the 1970 Bank Holding Company Act: Evidence from capital markets," Journal of Finance, 36(4) (1981), pp. 841-853.

Apostolou, N. G. and Crumbley, D. L., "Accounting for stock options: The controversy continues," The CPA Journal 71(5) (2005), pp. 34-39.

Avraham D, Selvaggi P, Vickery J., "A Structural View of Bank Holding Companies," Federal Reserve Bank of New York Economic Policy Review 18(2) (2012), pp. 65-82.

Ball, R, S.P. Kothari, and Robin, A., "The effect of international institutional factors on properties of accounting earnings," Journal of Accounting and Economics, 29(1) (2000), pp. $1-51$.

Barber, D., and Lyon, D., "Detecting abnormal operating performance: The empirical power and specification of test statistics," Journal of Financial Economics, 41(1) (1996), pp. 359399.

Beccalli E., Casu B. and Girardone C., "Efficiency and stock performance in European banking," Journal of Business Finance and Accounting 33(1-2) (2006), pp. 245-262.

Becher, D. A., Campbell, T. and Frye, M. B., "Incentive compensation for bank directors: The impact of deregulation,” Journal of Business 78(5) (2005), pp. 1753-1777.

Botosan, C. A., and Plumlee, M. A., "Stock option expense: The sword of Damocles revealed," Accounting Horizons, 15(4) (2001), pp. 311-327.

Brown, L. D. and Lee, Y.-J., "Changes in Option-Based Compensation Around the Issuance of SFAS 123R,” Journal of Business Finance \& Accounting, 38(9-10) (2011), pp. 1053-1095.

Chalmers, K. and Godfrey, J., "Expensing stock-based payments: A material concern?," Journal of International Accounting, Auditing and Taxation 14(2) (2005), pp. 157-173.

Chen, C.R., Steiner, T.L., Whyte, A.M., "Does stock option-based executive compensation induce risk-taking? An analysis of the banking industry," Journal of Banking and Finance 30(1) (2006), pp. 915-945.

Choudhary, P., "The Economic Consequences of Recognition Versus Disclosure: Evidence from Employee Stock Options" (2008). Available at SSRN: https://ssrn.com/abstract=1234020. Accessed at 18/01/2016. 
Choudhary, P., Rajgopal, S. and Venkatachalam, M., "Accelerated vesting of employee stock options in anticipation of FAS 123-R," Journal of Accounting Research 47(1) (2009), pp. 105-146.

Christian, C; J.S., Moffitt, and Suberly, L., "Fundamental analysis for evaluating bank performance," Bank Accounting \& Finance, 21(6) (2008), pp. 17-24.

Cocheo, S., "Performance picture: avoiding efficiency as a religion," American Bankers Association, ABA Banking Journal, 92(2) (2000), pp. S8-9.

Corbella, S. and Florio, C., "Issues arising for accounting harmonization: The case of stock options in Italy," Accounting Forum 34(3-4) (2010), pp.184-195.

Core, J., and Guay, W., "Stock option plans for non-executive employees," Journal of Financial Economics 61(2) (2001), pp. 253-287.

Core, J., Guay, W., and Kothari, S., "The economic dilution of employee stockoptions: Diluted EPS for valuation and financial reporting," Accounting Review 77(1) (2002), pp 627652.

Coulton, J., and Taylor, S., "Accounting for executive stock options: A case study in avoiding tough decisions", Australian Accounting Review, 12 (2) (2002a), pp.3-10.

Coulton, J., and Taylor, S., "Option awards for Australian CEOs: The who, what and why", Australian Accounting Review 12 (1) (2002b), 25-35.

European Commission, Enterprise Directorate-General., "Employee stock options. The legal and administrative environment for employee stock options in the EU," Final Report of the Expert Group (2003).

European Central Bank (ECB). "Banking structures report," (November, 2013), Available at: https://www.ecb.europa.eu/pub/pdf/other/bankingstructuresreport201311en.pdf.

Farber, D. F., Johnson, M. F., and Petroni, K. R., "Congressional intervention in the standardsetting process: an analysis of the stock option Accounting Reform Act of 2004," Accounting Horizons 21(1) (2007), pp. 1-22.

FASB., Statement of financial accounting standards 123: Accounting for Stock-Based Compensation, (Norwalk, CT: Financial Accounting Standards Board, 1995).

FASB., Statement of financial accounting standards 123 (Revised): Share-based payment, (Norwalk, CT: Financial Accounting Standards Board, 2004).

Goh, L., Joos, P. and Soonawalla, K. "Determinants and Valuation Implications of Compulsory Stock Option Disclosures in a Weak Regulatory Setting-The Case of France," Journal of International Financial Management and Accounting, 27(1) (2016), pp. 26-64

Hagendorff, J. and Vallascas, F., "CEO pay incentives and risk-taking: Evidence from bank acquisitions," Journal of Corporate Finance. 17(4) (2011), pp. 1078-1059. 
Hall, B. and Murphy, K,. “The trouble with stock options," Journal of Economic Perspectives 17(3) (2003), pp. 49-70.

Hess, K. and Francis, G., "Cost income ratio benchmarking in banking: a case study," Benchmarking: An International Journal 11(3) (2004), pp. 303-319.

International Accounting Standards Board (IASB), International financial reporting standard IFRS No. 2, share based payment, (London: International Accounting Standards Board, 2004).

Johnston, D., "Managing stock option expense: the manipulation of option-pricing model assumptions". Contemporary Accounting Research 23(2) (2006), pp. 394-425.

Mehran, H. and Rosenberg. J., "The Effect of CEO Stock Options on Bank Investment Choice, Borrowing, and Capital," Working paper. Federal Reserve Bank of New York, (2009).

Melissa B. F., "Equity-based compensation for employees: Firm performance and determinants," Journal of Financial Research, 27(1) (2004), pp. 31-54.

Murphy, K.J., Executive compensation. In: Orley, A., David, C. (Eds.), Handbook of Labor Economics 3, (North-Holland, Amsterdam, 1999)

Pendleton, A., Poutsma, E., Blasi, J., Kruse, D. and Sesil, J., Theoretical study on stock options in small and medium Enterprises, Final Report to the Enterprise-Directorate General, Commission of the European Communities, (2002), Available at: http://ec.europa.eu/enterprise/policies/sme/files/support_measures/stock_options/theoretical study_en.pdf. [accessed at 20-07-2015].

Seethamraju, C., and Zach. T., "Expensing stock options: The role of publicity," Working paper, (2003), Available at SSRN: http://ssrn.com/abstract=461760.

Schroeder, R., and Schauer, D. A., "SFAS No. 123R: The controversy and its economic consequences,” Managerial Auditing Journal 23(3) (2008), pp. 295-306.

Shiwakoti, R., and Rutherford, B., "Expensing of share-based payments and its impact on large UK companies,” The British Accounting Review 42(4) (2010), pp. 269-279.

Soderstrom, N.S., and Sun, K.J., "IFRS adoption and accounting quality: a review", European Accounting Review, 16(4) (2007), pp.675-702.

Stiroh, K., "Diversification in banking: Is noninterest income the answer?" Journal of Money, Credit, and Banking. 36(5) (2004), pp. 853-882.

Street, D. and Cereola, S., "Stock option compensation: impact of expense recognition on performance indicators of non-domestic companies listed in the U.S.," Journal of International Accounting, Auditing and Taxation 13(1) (2004), pp. 21-37.

Vance, D., "A meta-analysis of empirical materiality studies," The Journal of Applied Business Research, 27(5) (2011), pp. 53-72. 
Walker, D., "A review of corporate governance in UK banks and other financial industry entities"- Final recommendations., (16 July 2009).

Walker, J., "The use of performance-based remuneration: High versus low-growth firms", Australian Accounting Review, 20 (3)(2010), pp. 256-264. 


\section{Tables to be 'Inserted in the text':}

Table (1): Sample selection, countries and observations.

\section{Panel A: Sample selection}

\begin{tabular}{|c|c|c|c|c|c|c|c|c|c|}
\hline \multirow{2}{*}{ Description } & \multicolumn{3}{|c|}{ US } & \multicolumn{3}{|c|}{ EU } & \multicolumn{3}{|c|}{ Total } \\
\hline & CBs & BHCs & Total & $\mathrm{CBs}$ & BHCs & Total & CBs & BHCs & Total \\
\hline Initial Sample & 20 & 90 & 110 & 58 & 28 & 86 & 78 & 118 & 196 \\
\hline BHCs with less than $25 \%$ net loan to total assets & 0 & 3 & 3 & 0 & 14 & 14 & 0 & 17 & 17 \\
\hline Banks that do not publish annual reports in English & 0 & 0 & 0 & 5 & 0 & 5 & 5 & 0 & 5 \\
\hline Banks that do not grant share-based compensations over 3 years & 4 & 0 & 4 & 22 & 1 & 23 & 26 & 1 & 27 \\
\hline Banks with missing accounting data and market valuations & 1 & 0 & 1 & 1 & 0 & 1 & 2 & 0 & 2 \\
\hline The final sample & 15 & 87 & 102 & 30 & 13 & 43 & 45 & 100 & 145 \\
\hline
\end{tabular}

Panel B: Countries and observations in the final sample of banks from 2004-2011

\begin{tabular}{|l|c|c|c|c|}
\hline Country & CBs & BHCs & Total & Years-observations \\
\hline US & 15 & 87 & 102 & 702 \\
EU & 30 & 13 & 43 & 308 \\
\hline United Kingdom & 0 & 5 & 5 & 40 \\
Italy & 6 & 0 & 6 & 45 \\
Germany & 4 & 0 & 4 & 27 \\
Greece & 4 & 0 & 4 & 19 \\
Spain & 4 & 0 & 4 & 22 \\
France & 3 & 0 & 3 & 24 \\
Netherlands & 1 & 2 & 3 & 24 \\
Austria & 1 & 1 & 2 & 16 \\
Belgium & 0 & 2 & 2 & 15 \\
Denmark & 2 & 0 & 2 & 15 \\
Ireland & 2 & 0 & 2 & 13 \\
Portugal & 1 & 1 & 2 & 16 \\
Sweden & 1 & 1 & 2 & 16 \\
Luxembourg & 0 & 1 & 1 & 8 \\
Finland & 1 & 0 & 1 & 8 \\
\hline Total & 45 & 100 & 145 & 1010 \\
\hline
\end{tabular}

Table (2): Descriptive statistic ${ }^{\alpha}$

\begin{tabular}{|c|c|c|c|c|c|c|c|c|c|}
\hline \multirow{2}{*}{ Item/ \$m } & \multicolumn{3}{|c|}{ EU (274 Observations) } & \multicolumn{3}{|c|}{ US (609 Observations) } & \multicolumn{3}{|c|}{ Total (883 Observations) } \\
\hline & Mean & Median & S.D & Mean & Median & S.D & Mean & Median & S.D \\
\hline Total Assets & 686449.5 & 249891.1 & 936023.9 & 93207.9 & 8225.3 & 343925.7 & 277294.2 & 13615.1 & 654316.8 \\
\hline Net Interest Income & 8260.2 & 3847.3 & 12268.2 & 2397.7 & 256.8 & 8283.3 & 4216.9 & 402.6 & 10062.2 \\
\hline Net Profit & 2474.8 & 845.9 & 6440.5 & 523.45 & 57.34 & 2767.79 & 1128.96 & 82.11 & 4351.54 \\
\hline Operating Income & 18087.5 & 8227.7 & 22394.9 & 4524.1 & 343.2 & 15824.7 & 8732.9 & 583.8 & 19164.5 \\
\hline Pre-tax Profit & 3280.0 & 979.3 & 7298.7 & 709.61 & 77.47 & 4071.32 & 1507.23 & 114.56 & 5415.76 \\
\hline Opening Shareholders Equity (BV) & 22716.8 & 10386.9 & 29304.9 & 7070.5 & 784.7 & 24859.6 & 11925.6 & 1211.4 & 27281.4 \\
\hline Market Capitalization & 27400.1 & 12467.1 & 37722.7 & 8830.6 & 1163.7 & 28766.5 & 14592.8 & 1614.8 & 32935.9 \\
\hline Employee No & 55017.0 & 23916.0 & 67263.6 & 15190.3 & 1638.0 & 50523.2 & 27548.8 & 2600.0 & 59159.7 \\
\hline SBC Expense & 166.1 & 13.9 & 378.3 & 87.1 & 3.7 & 418.2 & 111.7 & 4.9 & 407.7 \\
\hline SBC Exp/ Staff Exp b \% & 1.89 & 1.26 & 2.12 & 4.52 & 3.18 & 4.62 & 3.70 & 2.53 & 4.19 \\
\hline
\end{tabular}

$\alpha$ All figures are reported for the post-adoption years combined and in US currency (\$) using the exchange rate at each closing period.

${ }^{b}$ Staff expenses represent wages and benefits paid to employees and officers of the company. It includes all employee wages, fixed and variable compensations and other benefits such as health insurance and contributions to pension plans. 
Table (3): SBC expense relative to selected key variables $\alpha$

\begin{tabular}{|c|c|c|c|c|c|c|c|c|c|c|c|c|}
\hline \multirow{2}{*}{ Item } & \multicolumn{4}{|c|}{ EU \% } & \multicolumn{4}{|c|}{ US \% } & \multicolumn{4}{|c|}{ Total \% } \\
\hline & Obvs & Mean & Median & S.D & Obvs & Mean & Median & S.D & Obvs & Mean & Median & S.D \\
\hline SBC Exp Relative to Total Assets & 274 & 0.02 & 0.01 & 0.02 & 609 & 0.06 & 0.04 & 0.06 & 883 & 0.05 & 0.03 & 0.05 \\
\hline SBC Exp Relative to Adjusted Pre-tax Profit & 244 & 3.02 & 1.52 & 4.77 & 519 & 6.12 & 3.50 & 8.08 & 763 & 5.13 & 2.76 & 7.33 \\
\hline SBC Exp Relative to Adjusted Pre-tax Loss & 30 & 6.22 & 0.92 & 9.90 & 90 & 8.57 & 3.87 & 9.69 & 120 & 7.98 & 3.36 & 9.76 \\
\hline SBC Exp Relative to Opening Shareholders' equity & 274 & 0.51 & 0.23 & 0.75 & 609 & 0.66 & 0.49 & 0.64 & 883 & 0.61 & 0.42 & 0.68 \\
\hline
\end{tabular}

${ }^{\alpha}$ All figures are reported for the post-adoption years combined and in US currency (\$) using the exchange rate at each closing period.

Table (4): Panel (A): The impact of expensing SBC schemes on selected financial measures.

\begin{tabular}{|c|c|c|c|c|c|c|c|c|c|c|c|c|}
\hline \multirow{2}{*}{ Financial ratios ${ }^{b}$} & \multicolumn{4}{|c|}{$\mathbf{E U}$} & \multicolumn{4}{|c|}{ US } & \multicolumn{4}{|c|}{ Total } \\
\hline & $\mathbf{N}$ & mean & median & S.D & $\mathbf{N}$ & mean & median & S.D & $\mathbf{N}$ & mean & median & S.D \\
\hline Return on equity (ROE) & & & & & & & & & & & & \\
\hline Difference $^{\alpha}$ & 274 & 0.42 & 0.22 & 0.54 & 609 & 0.59 & 0.47 & 0.48 & 883 & 0.54 & 0.40 & 0.50 \\
\hline $\begin{array}{l}\text { Differences as a percentage of reported } \mathrm{ROE}^{\mathrm{c}} \\
\text { Eearnings per share (Diluted) }\end{array}$ & 246 & 3.76 & 1.98 & 5.04 & 519 & 9.55 & 5.06 & 15.02 & 765 & 7.69 & 3.96 & 12.98 \\
\hline Difference & 274 & 7.93 & 2.01 & 16.7 & 609 & 9.96 & 6.27 & 10.07 & 883 & 9.33 & 5.26 & 12.57 \\
\hline $\begin{array}{l}\text { Differences as a percentage of reported EPS (Diluted) }{ }^{\mathrm{c}} \\
\text { Cost to income ratio }\end{array}$ & 244 & 4.23 & 2.14 & 5.84 & 508 & 9.32 & 5.31 & 12.63 & 752 & 7.67 & 4.06 & 11.15 \\
\hline$\overline{\text { Difference }}$ & 274 & 0.64 & 0.38 & 0.75 & 609 & 1.30 & 0.97 & 1.12 & 883 & 1.10 & 0.77 & 1.06 \\
\hline Differences as a percentage of reported CIR & 274 & 1.04 & 0.61 & 1.20 & 609 & 2.12 & 1.61 & 1.77 & 883 & 1.79 & 1.24 & 1.69 \\
\hline Option expense as a percentage of opening shareholders' equity & 274 & 0.51 & 0.23 & 0.75 & 609 & 0.66 & 0.49 & 0.64 & 883 & 0.61 & 0.42 & 0.68 \\
\hline
\end{tabular}

Option expense as a percentage of opening shareholders' equity

${ }^{\alpha}$ Difference is calculated as an absolute difference between used ratios adjusted for SBC expense and those reported in the annual financial reporting. The difference is measured in cents. Differences as a percentage is calculated as follow: ratios adjusted for SBC expense minus reported ratio and the difference is divided by reported ratio.

b All figures are reported for the post-adoption years combined. Return on equity (ROE) is calculated as net profit after tax divided by average shareholders' equity excluding non-controlling interests. Diluted earnings per share (DEPS) is measured by profit attributable to equity shareholders to the weighted average numbers of shares on issue plus dilution shares. Cost to income ratio (CIR) is a bank's operating costs relative to its total net interest and non-interest income (Christian, et al 2008).

c The number of observations for reported differences as a percentage is different from that in the reported differences as absolute figures because when banks reported losses over the sample period under examination the observation has been omitted. Chalmers and Godfrey (2005) and Shiwakoti and Rutherford (2010) also follow the same methodology. The reason being that such losses result in nonsensical percentages owing to the negative denominators. This follows Barber and Lyon (1996, p 394) who commented that: '...if ROA is negative in either year over which the percentage change is calculated, the result is nonsensical. Consequently, researchers are forced to discard firms that experience losses over the sample period under consideration'. 
Table (4): Panel (B): The impact of expensing SBC schemes on selected financial measures in the EU sample.

\begin{tabular}{|c|c|c|c|c|c|c|c|c|c|c|c|c|c|c|c|c|c|c|c|c|c|c|c|c|c|c|c|c|c|c|c|c|}
\hline \multirow{2}{*}{$\begin{array}{l}\text { Financial ratios }^{\mathrm{c}} \\
\text { Return on equity }(\mathrm{ROE})\end{array}$} & \multicolumn{4}{|c|}{\begin{tabular}{|c|c|}
\multicolumn{2}{|c|}{2004} \\
n & mean $50 \%$ S.D \\
\end{tabular}} & \multirow{2}{*}{\multicolumn{4}{|c|}{\begin{tabular}{|c|}
2005 \\
n \\
\end{tabular}}} & \multirow{2}{*}{\multicolumn{4}{|c|}{\begin{tabular}{|c|}
2006 \\
n \\
\end{tabular}}} & \multirow{2}{*}{\multicolumn{4}{|c|}{\begin{tabular}{|c|c|}
\multicolumn{2}{|c|}{2007} \\
n & mean $\mathbf{5 0 \%}$ S.D \\
\end{tabular}}} & \multirow{2}{*}{\multicolumn{4}{|c|}{\begin{tabular}{|c|c|}
\multicolumn{2}{|c|}{2008} \\
n & mean $50 \%$ S.D \\
\end{tabular}}} & \multirow{2}{*}{\multicolumn{4}{|c|}{$\begin{array}{c}2009 \\
\text { n mean 50\% S.D } \\
\end{array}$}} & \multicolumn{4}{|c|}{\begin{tabular}{|c|c}
\multicolumn{2}{|c}{2010} \\
$\mathrm{n} \quad$ mean $50 \%$ S.D \\
\end{tabular}} & \multicolumn{4}{|c|}{ 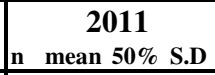 } \\
\hline & & & & & & & & & & & & & & & & & & & & & & & & & & & & & & & & \\
\hline Difference $^{b}$ & & 0.54 & 0.32 & 0.73 & 36 & 0.50 & 0.32 & 0.64 & 38 & 0.68 & 0.40 & 0.82 & 41 & 0.43 & 0.27 & 0.43 & 41 & 0.25 & 0.19 & 0.26 & 42 & 0.41 & 0.18 & 0.56 & 39 & 0.35 & 0.14 & 0.53 & 37 & 0.33 & 0.12 & 0.47 \\
\hline IIE & 33 & 2.83 & 1.83 & 3.30 & 35 & 2.71 & 1.96 & 2.53 & 38 & 3.19 & 1.84 & 4.02 & 41 & 2.83 & 1.40 & 3.90 & 33 & 3.56 & 2.06 & 4.61 & 34 & 5.09 & 2.29 & 5.69 & 36 & 3.63 & 1.52 & 4.97 & 29 & 5.96 & 2.58 & 8.25 \\
\hline & 34 & 3.91 & 2.70 & 3.85 & 36 & 8.26 & 3.17 & 15.11 & 38 & 11.09 & 3.82 & 19.12 & 41 & & 3.02 & 6.32 & 41 & 3. & 1.49 & 5.39 & 42 & 87 & 1.12 & 23.91 & 139 & 8.92 & 1.08 & 20.53 & 37 & 7.49 & 1.39 & 17.06 \\
\hline & 3 & 3.71 & 2.16 & 4.70 & 35 & 2.99 & 2.23 & 2.72 & 38 & 3.51 & 2.07 & 4.22 & 41 & 3.00 & 1.68 & 3.99 & 33 & 3.59 & 2.06 & 4.62 & 34 & 6.60 & 2.83 & 7.5 & 35 & 4.15 & 1.35 & 6.17 & 28 & 6.5 & 2.71 & 9.40 \\
\hline & & 0. & 0.2 & & 36 & & 0. & 0. & & & & 0. & 41 & & & 0.65 & 41 & & & & 42 & & & & 39 & & & 1.02 & 37 & & & 0.97 \\
\hline 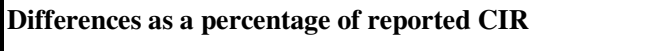 & 34 & 1.06 & 0.51 & 1.45 & 36 & 1.09 & 0.82 & 0.99 & 38 & 1.43 & 0.97 & 1.38 & 41 & 1.13 & 0.68 & 1.14 & 41 & 0.66 & 0.54 & 0.67 & 42 & 0.87 & 0.55 & 0.96 & 39 & 1.10 & 0.48 & 1.52 & 37 & 1.04 & 0.46 & 1.47 \\
\hline $\begin{array}{l}\text { quity } \\
\text { quitense as a percentage of opening sharenolders }\end{array}$ & $p^{34}$ & 0.63 & 0.34 & 0.98 & & 0.58 & 0.32 & 0.73 & 38 & 0.82 & 0.49 & 1.00 & 41 & 0.58 & 0.37 & 0.77 & 41 & 0.30 & 0.18 & & & 0.55 & 0.22 & 0.80 & 39 & 0.39 & 0.15 & 0.68 & 37 & 0.34 & 0.12 & 20.57 \\
\hline
\end{tabular}

\section{Table (4): Panel (C): The impact of expensing SBC schemes on selected financial measures in the US sample}

\begin{tabular}{|c|c|c|c|c|c|c|c|c|c|c|c|c|c|c|c|c|c|c|c|c|c|c|c|c|c|c|c|c|c|}
\hline \multirow{2}{*}{$\frac{\text { Financial ratios }^{c}}{\text { Return on equity }(\text { ROE })}$} & \multirow[t]{2}{*}{$2004^{\alpha}$} & \multirow{2}{*}{ n } & \multirow{2}{*}{\multicolumn{2}{|c|}{$\begin{array}{c}2005 \\
\text { mean } 50 \%\end{array}$}} & \multirow{2}{*}{ S.D } & \multirow{2}{*}{ n } & \multirow{2}{*}{\multicolumn{2}{|c|}{$\begin{array}{c}2006 \\
\text { mean } 50 \% \\
\end{array}$}} & \multirow{2}{*}{ S.D } & \multirow{2}{*}{$\mathrm{n}$} & \multirow{2}{*}{\multicolumn{2}{|c|}{$\begin{array}{c}2007 \\
\text { mean } 50 \% \\
\end{array}$}} & \multirow{2}{*}{ S.D } & \multirow{2}{*}{ n } & \multirow{2}{*}{\multicolumn{2}{|c|}{$\begin{array}{c}2008 \\
\text { mean } 50 \% \\
\end{array}$}} & \multirow{2}{*}{ S.D } & \multirow{2}{*}{$\mathrm{n}$} & \multirow{2}{*}{\multicolumn{2}{|c|}{$\begin{array}{c}2009 \\
\text { mean } 50 \% \\
\end{array}$}} & \multirow{2}{*}{ S.D } & \multirow{2}{*}{ n } & \multirow{2}{*}{\multicolumn{2}{|c|}{$\begin{array}{c}2010 \\
\text { mean } 50 \%\end{array}$}} & \multirow{2}{*}{ S.D } & \multirow{2}{*}{\multicolumn{3}{|c|}{$\begin{array}{r}2011 \\
\text { an } 50 \%\end{array}$}} & \multirow{2}{*}{ S.D } \\
\hline & & & & & & & & & & & & & & & & & & & & & & & & & & & & & \\
\hline$\overline{\text { Difference } \mathrm{b}}$ & & 93 & 0.91 & 0.76 & 0.61 & 99 & 0.61 & 0.53 & 0.50 & 102 & 0.64 & 0.51 & 0.48 & 120 & 0.64 & 0.48 & 0.52 & 102 & 0.59 & 0.44 & 0.51 & 102 & 0.55 & 0.43 & 0.43 & 102 & 0.53 & 0.43 & 0.39 \\
\hline $\begin{array}{l}\text { Differences as a percentage of } \\
\text { reported ROE } \\
\text { Eearning per share (Diluted) }\end{array}$ & & 92 & 8.76 & 5.35 & 9.41 & 97 & 5.24 & 3.98 & 4.98 & 98 & 11.02 & 4.74 & 18.19 & 80 & 13.11 & 6.19 & 16.43 & 69 & 14.14 & 5.32 & 26.56 & 82 & 8.62 & 5.92 & 8.37 & 93 & 6.83 & 5.72 & 4.97 \\
\hline Difference & & 93 & 13.12 & 10.21 & 10.23 & 99 & 10.22 & 5.82 & 11.82 & 102 & 10.89 & 6.50 & 10.85 & 102 & 10.93 & 6.72 & 10.44 & 102 & 9.46 & 6.23 & 9.08 & 102 & 8.78 & 5.91 & 8.47 & 102 & 9.50 & 6.52 & 9.52 \\
\hline $\begin{array}{l}\text { Differences as a percentage of } \\
\text { reported EPS (Diluted) } \\
\text { Cost to income ratio (CIR) }\end{array}$ & & 92 & 8.74 & 5.35 & 9.43 & 97 & 5.21 & 3.80 & 4.97 & 98 & 11.13 & 4.71 & 18.28 & 79 & 12.70 & 6.04 & 15.69 & 65 & 11.79 & 5.41 & 14.98 & 78 & 9.25 & 6.04 & 9.09 & 91 & 7.12 & 5.72 & 5.23 \\
\hline$\overline{\text { Difference }}$ & & 93 & 1.93 & 1.31 & 1.71 & 99 & 1.26 & 1.05 & 1.02 & 102 & 1.53 & 1.08 & 1.37 & 102 & 1.56 & 1.00 & 1.45 & 102 & 1.18 & 0.86 & 0.96 & 102 & 1.13 & 0.85 & 0.86 & 102 & 1.16 & 0.95 & 0.81 \\
\hline $\begin{array}{l}\text { Differences as a percentage of } \\
\text { reported CIR }\end{array}$ & & 93 & 3.84 & 2.64 & 3.57 & 99 & 2.23 & 1.73 & 1.84 & 102 & 2.48 & 1.79 & 2.06 & 102 & 2.36 & 1.60 & 2.04 & 102 & 1.97 & 1.41 & 1.69 & 102 & 1.84 & 1.29 & 1.46 & 102 & 1.87 & 1.42 & 1.37 \\
\hline $\begin{array}{l}\text { SBC expense as a percentage of } \\
\text { opening shareholders' equity }\end{array}$ & & 93 & 1.01 & 0.81 & 0.83 & 99 & 0.71 & 0.57 & 0.67 & 102 & 0.68 & 0.55 & 0.58 & 102 & 0.70 & 0.50 & 0.67 & 102 & 0.66 & 0.47 & 0.66 & 102 & 0.63 & 0.47 & 0.79 & 102 & 0.56 & 0.45 & 0.44 \\
\hline
\end{tabular}

${ }^{\alpha}$ The pre-adoption year for the US sample is 2005 , whereas it is 2004 for the EU sample because the mandatory IFRS2 was first applied to accounting periods starting 1st January 2005 , whereas FAS123 commenced on reporting periods beginning after June 15,2005 , which implies that financial reporting statements for 2006 is the first adoption year.

$\mathrm{b}$ Difference is calculated as an absolute difference between used ratios adjusted for SBC expense and those reported in the annual financial reporting. The difference is measured in cents. Differences as a percentage is calculated as follow: ratios adjusted for SBC expense minus reported ratio and the difference is divided by reported ratio.

${ }^{c}$ All figures are reported for the post-adoption years combined. Return on equity (ROE) is calculated as net profit after tax divided by average shareholders' equity excluding non-controlling interests. Diluted earnings per share (DEPS) is measured by profit attributable to equity shareholders to the weighted average numbers of shares on issue plus dilution shares. Cost to income ratio (CIR) is a bank's operating costs relative to its total net interest and non-interest income (Christian, et al 2008). 
Table 5 (A): Selected performance measures with and without adjustment for SBC expense over the post and pre IFRS2/FAS123R adoption period.

\begin{tabular}{|c|c|c|c|c|c|c|c|c|c|c|}
\hline & \multicolumn{5}{|c|}{ UU Banks over the post IFRS2 adoption period (2005-2011) } & \multicolumn{5}{|c|}{ US Banks over the post FAS123R adoption period (2006-2011) } \\
\hline Descriptions & ROA $^{\alpha}$ & $\operatorname{ROE}^{\alpha}$ & Diluted EPS $\alpha$ & CIR & PBT & $\mathbf{R O A}^{\alpha}$ & ROE $^{\alpha}$ & Diluted EPS $\alpha$ & CIR & PBT \\
\hline Mean Adjusted & 0.56 & 10.78 & 191.44 & 63.86 & 3446.14 & 0.67 & 5.83 & 110.57 & 65.34 & 796.72 \\
\hline Mean Not Adjusted & 0.54 & 10.36 & 183.51 & 63.21 & 3280.05 & 0.61 & 5.23 & 100.61 & 64.04 & 709.61 \\
\hline$T$ test for mean differences ${ }^{b}$ & $14.74 * * *$ & $11.36 * * *$ & $5.1 * * *$ & $11.2^{* * *}$ & $7.27 * * *$ & $24.5^{* * * *}$ & $26.9^{* * *}$ & $20.7 * * *$ & $20.4 * * *$ & $5.14 * * *$ \\
\hline Median Adjusted & 0.55 & 11.86 & 105.5 & 61.7 & 996.65 & 0.87 & 8.89 & 107.37 & 63.47 & 82.7 \\
\hline Median Not Adjusted & 0.54 & 11.64 & 103.49 & 61.06 & 979.25 & 0.83 & 8.42 & 101.1 & 62.17 & 77.47 \\
\hline WSR test for Med differences ${ }^{b}$ & $14.06^{* * * *}$ & $13.85 * * *$ & $13.67 * * *$ & $13.91^{* * * *}$ & $13.75^{* * * *}$ & $21.37 * * *$ & $21.38^{* * * *}$ & $21.36^{* * *}$ & $21.37 * * *$ & $21.37 * * *$ \\
\hline & \multicolumn{5}{|c|}{ EU Banks over the pre IFRS2 adoption period (2004) } & \multicolumn{5}{|c|}{ US Banks over the pre FAS123R adoption period (2005) } \\
\hline Mean Adjusted & 0.68 & 20.38 & 229.49 & 64.33 & 4134.35 & 1.76 & 14.65 & 213.9 & 56.28 & 1337.66 \\
\hline Mean Not Adjusted & 0.66 & 19.84 & 225.58 & 63.75 & 4013.85 & 1.65 & 13.74 & 200.78 & 54.35 & 1272.23 \\
\hline$T$ test for mean differences & $4.47^{* * *}$ & $3.78^{* * *}$ & $1.59^{*}$ & $3.98^{* * *}$ & $2.31 * *$ & $8.58 * * *$ & $11.39 * * *$ & $10.11 * * *$ & $10.52 * * *$ & $2.36^{* *}$ \\
\hline Media & 0.7 & 16.68 & 103.12 & 61.59 & 1435.31 & 1.58 & 14.01 & 183.58 & 57.72 & 107.54 \\
\hline Median Not Adjusted & 0.69 & 16.36 & 100.42 & 61.01 & 1423.66 & 1.49 & 13.25 & 173.37 & 56.41 & 105.99 \\
\hline WSR test for Med differences ${ }^{b}$ & $5.08 * * *$ & $5.08 * * *$ & $5.86^{* * * *}$ & $5.1^{* * * *}$ & $5.08 * * *$ & $8.37 * * *$ & $8.38 * * *$ & $8.37 * * *$ & $8.37 * * *$ & $8.37 * * *$ \\
\hline
\end{tabular}

Table 5 (B): The difference in the change of the selected performance measures exclusively due to the introduction of IFRS2/FAS123R

\begin{tabular}{|c|c|c|c|c|c|c|c|c|c|c|}
\hline \multicolumn{6}{|c|}{ EU Banks (2004-2005) } & \multicolumn{5}{|c|}{ US Banks (2005-2006) } \\
\hline Descriptions & $\triangle \mathrm{ROA} \%$ & $\triangle \mathrm{ROE} \%$ & $\triangle$ DEPS \% & $\Delta$ CIR\% & $\triangle$ РBT \% & $\triangle \mathbf{R O A} \%$ & $\triangle \mathrm{ROE} \%$ & $\triangle$ DEPS\% & $\Delta$ CIR\% & $\triangle \mathrm{PBT} \%$ \\
\hline Mean Difference in the change ${ }^{c}$ & $(3.51)$ & $(3.49)$ & $(5.61)$ & $(1.08)$ & $(5.59)$ & $(4.89)$ & $(5.62)$ & $(5.85)$ & $(2.61)$ & $(5.45)$ \\
\hline$T$ test for mean differences & $3.54 * * *$ & $3.47 * * *$ & $3.19 * * *$ & $5.63^{* * *}$ & $1.89 *$ & $6.71^{* * *}$ & $6.76^{* * *}$ & $7.51 * * *$ & $9.04 * * *$ & $4.31 * * *$ \\
\hline $\begin{array}{l}\text { Median Difference in the } \\
\text { change }\end{array}$ & $(2.02)$ & $(2.02)$ & $(3.21)$ & $(0.75)$ & $(1.73)$ & $(3.19)$ & $(3.8)$ & $(4.13)$ & $(1.82)$ & $(3.09)$ \\
\hline WSR test for Med difference & $5.08 * * *$ & $5.08 * * *$ & $5.86 * * *$ & $5.1 * * *$ & $5.08 * * *$ & $8.37 * * *$ & $8.38 * * *$ & $8.37 * * *$ & $8.37 * * *$ & $8.37 * * *$ \\
\hline
\end{tabular}

${ }^{a}$ ROA, ROE and Diluted EPS are reported in cents

b $* * *$ and $* * *$ signify significant at $10 \%, 5 \%$ and $1 \%$ respectively. Mean adjusted ratio is the ratio after adjusting SBC expense and non-adjusted ratio is calculated from the reported amount.

${ }^{c}$ The difference in the change reflects the difference in the annual change of the selected ratios without and with adjusting for options expense in the first adoption year. The reported figures represent the average difference

in the change $(\Delta)$ of the selected performance measures over the period, 2004-2005 for EU banks and 2005-2006 for US banks, exclusively due to the mandatory introduction of IFRS2/FAS123R 
Table (6) ${ }^{\mathrm{a}}$ : Comparison of SBC expense and SBC expense relative to staff expenses using $\mathrm{T}$ and $\mathrm{U}$ test.

\begin{tabular}{|c|c|c|c|c|c|c|c|c|}
\hline \multirow{2}{*}{ Year / Description } & \multicolumn{2}{|c|}{ SBC $\operatorname{Exp}(\mathbf{E U})$} & \multicolumn{2}{|c|}{ SBC Exp/Staff Exp ${ }^{c}$ (EU) } & \multicolumn{2}{|c|}{ SBC $\operatorname{Exp}($ US) } & \multicolumn{2}{|c|}{ SBC Exp / Staff Exp (US) } \\
\hline & Mean & Median & Mean & Median & Mean & Median & Mean & Median \\
\hline pre-adoption & 120.5 & 16.35 & 1.6 & 0.96 & 65.43 & 4.56 & 6.25 & 4.59 \\
\hline post-adoption & 166.1 & 13.87 & 1.89 & 1.26 & 87.11 & 3.6 & 4.52 & 3.18 \\
\hline A-pre-crisis & 147.9 & 25.24 & 2.07 & 1.52 & 81.94 & 2.95 & 4.63 & 3.29 \\
\hline B-2008 & 122.37 & 8.89 & 1.47 & 1.03 & 83.8 & 3.79 & 4.91 & 3.39 \\
\hline C- post-crisis & 199.02 & 9.13 & 1.87 & 1.08 & 91.61 & 3.89 & 4.31 & 3.07 \\
\hline $\mathrm{T}(\mathrm{U})$ test for median (mean) differences (post vs pre-adoption) ${ }^{\mathrm{b}}$ & 0.81 & -0.01 & 0.87 & 0.61 & 0.67 & $-1.73 *$ & $-2.83 * * *$ & $-3.81 * * *$ \\
\hline $\mathrm{T}$ (U) test for median (mean) differences (pre-crisis vs pre-adoption) & 0.45 & 0.76 & $1.91 *$ & $1.95^{*}$ & 1.01 & $2.04 * *$ & $-2.47^{* *}$ & $-2.93 * * *$ \\
\hline $\mathrm{T}$ (U) test for median (mean) differences (2008 vs pre-crisis) & -0.41 & $-1.73^{*}$ & $-3.31 * * *$ & $-2.63 * * *$ & 0.48 & 0.7 & 0.69 & 0.36 \\
\hline $\mathrm{T}(\mathrm{U})$ test for median (mean) differences (post-crisis vs 2008) & 1.18 & 0.8 & 0.98 & 0.59 & 0.16 & 0.13 & -1.11 & 1.25 \\
\hline $\mathrm{T}$ (U) test for median (mean) differences (post-crisis vs pre-crisis) & 1.02 & -1.63 & -0.71 & $-2.5^{* *}$ & 0.26 & 1.09 & -1.48 & -0.99 \\
\hline
\end{tabular}

This table examines whether the adoption of IFRS2/FAS123R has reduced SBC expense in absolute values and relative to total staff expense in EU and US banks after divide our sample into four distinctive periods: i) Pre-adoption, 2004 and 2005 for EU and US banks, respectively; ii) pre-global financial crisis: from the first year of IFRS2/FAS123R adoption until 2007; iii) the global financial crisis in 2008; iv) post-global financial crisis, 2009-2011. Specifically, it compares between the pre-adoption and post-adoption period, pre-adoption period and pre-global financial crisis, and over the three phases of the post-adoption period (i.e. pre-global financial crisis, the global financial crisis and post-global financial crisis)

b $* * *$ and $* * *$ signify significant at $10 \%, 5 \%$ and $1 \%$ respectively

Staff expenses include employees' salaries, benefits and compensations. 
Table (7): The impact of IFRS2/FAS123R on selected financial measures (According to size and growth rate) ${ }^{\alpha}$.

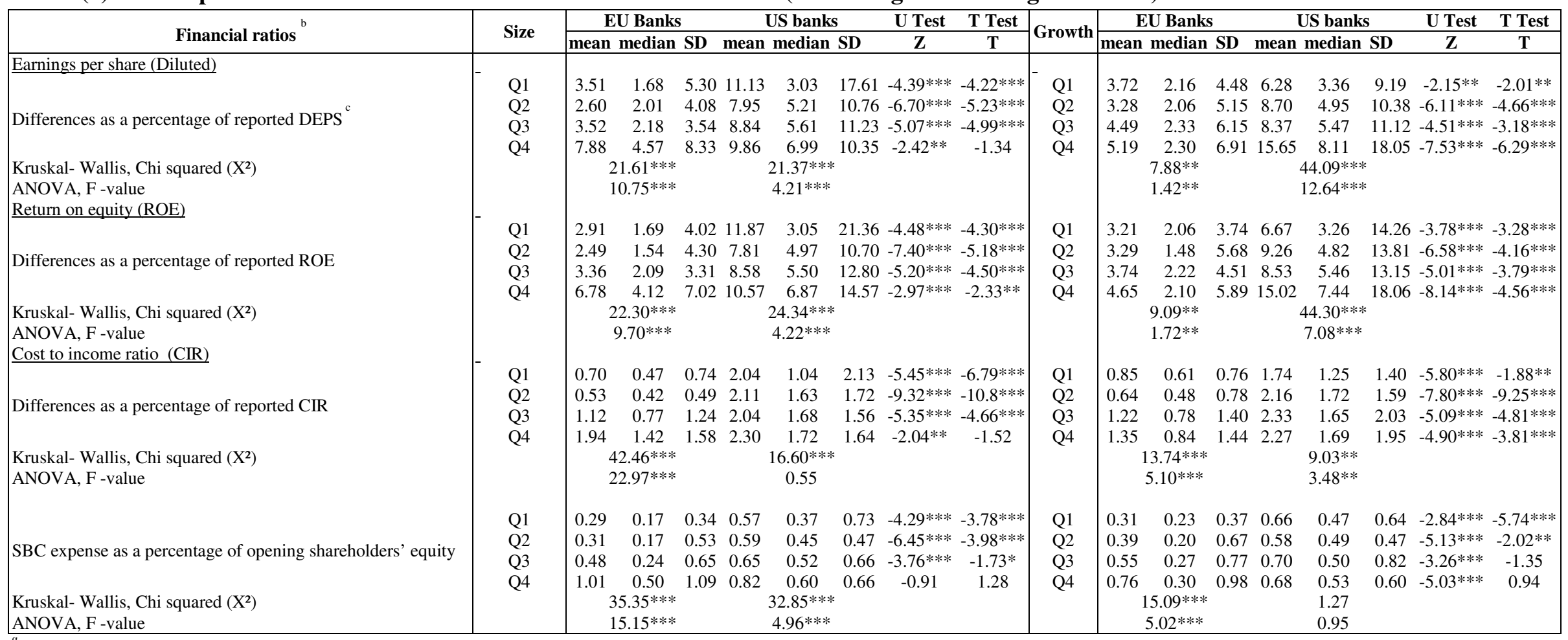

${ }^{\alpha}$ Each of the EU and US sample banks has been divided into four separate sub-samples, based on the quartiles of banks' average total assets (a proxy for size) and market to book value (a proxy for growth rate).

b All figures are reported for the post-adoption years combined. Return on equity (ROE) is calculated as net profit after tax divided by average shareholders' equity excluding non-controlling interests. Diluted earnings per share (DEPS) is measured by profit attributable to equity shareholders to the weighted average numbers of shares on issue plus dilution shares. Cost to income ratio (CIR) is a bank's operating costs relative to its total net interest and non-interest income (Christian, et al 2008).

${ }^{c}$ Differences as a percentage is calculated as follow: ratios adjusted for SBC expense minus ratio as reported in banks and the difference is divided by reported ratio. 
Table (8): The impact of IFRS2/FAS123R on selected financial measures (According to specialisation and variation of traditional banking activities).

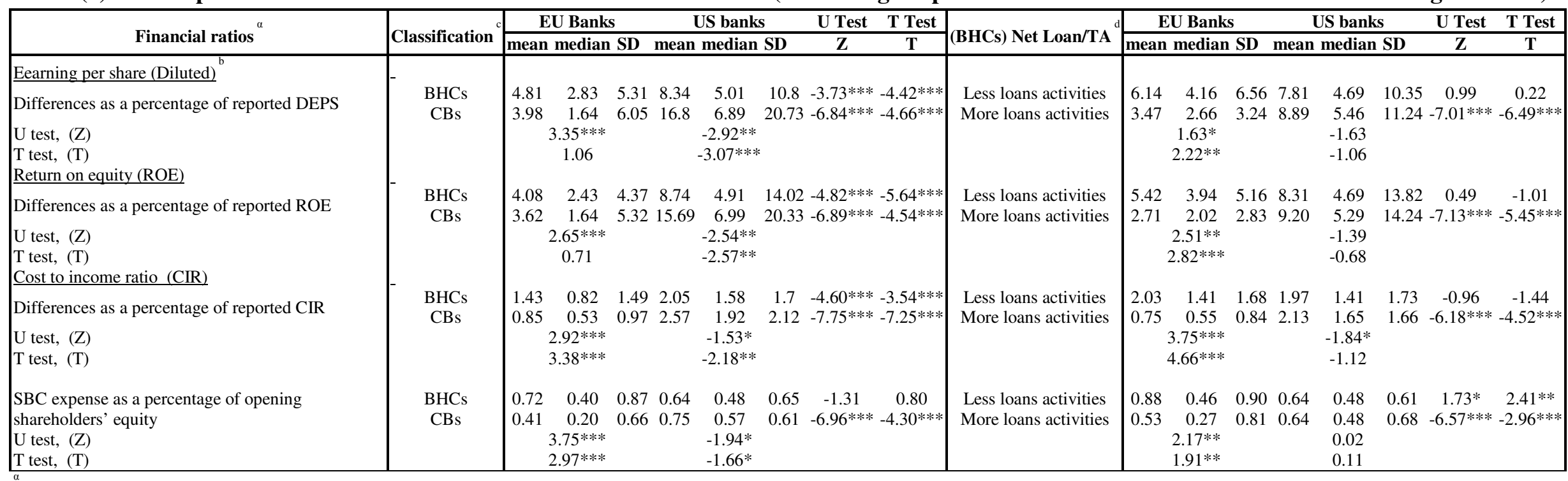

All figures are reported for the post-adoption years combined. Return on equity (ROE) is calculated as net profit after tax divided by average shareholders' equity excluding non-controlling interests. Diluted earnings per share (DEPS) is measured by profit attributable to equity shareholders to the weighted average numbers of shares on issue plus dilution shares. Cost to income ratio (CIR) is a bank's operating costs relative to its total net interest and non-interest income (Christian, et al 2008).

${ }^{\mathrm{b}}$ Differences as a percentage is calculated as follow: ratios adjusted for SBC expense minus ratio as reported in banks and the difference is divided by reported ratio.

'Each of the EU and US sample banks has been divided into two subsamples according to the difference in banks' organisational structure (classification to commercial and bank-holding companies).

'Each of the EU and US sample Bank Holding companies (BHC) has been divided into two subsamples based on the median of banks' average net loan to total assets as a proxy for the variation in traditional banking activities. 
Have you a number for this?????:

Eg Fig, 2 so in the text can put seeFig 2.

Figures to be 'inserted in the text:

Cash-settled based payment in US and EU

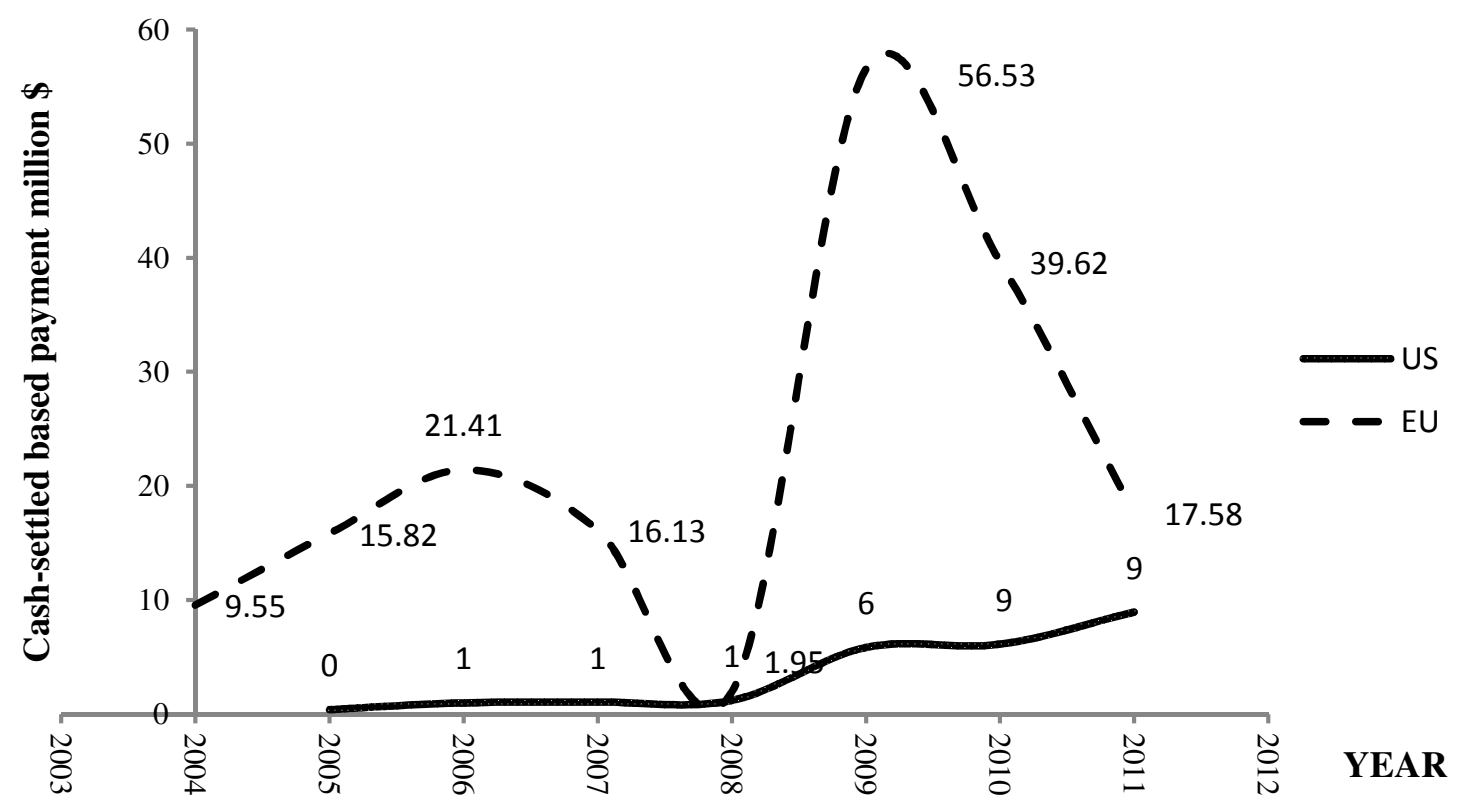


